\title{
Cos'è il fascismo?
}

\section{Emilio Gentile}

Storicamente, 2 (2006).

ISSN: 1825-411X. Art. no. 69. DOI: 10.12977/stor542

16 novembre 2006

\section{Prof. Emilio Gentile}

(Università La Sapienza di Roma)

Cos'è il fascismo?

(conferenza)

[[figure]]figures/2006/Gentile_1/Gentile_1_2006_01.jpg[[/figure]] 